\title{
Interpretation of Dynamic Sediment Characteristic based on Microtremor Analysis in Prambanan Region, Sleman Yogyakarta and Klaten Central Java, Indonesia
}

\author{
Interpretasi Karakteristik Dinamika Sedimen Berdasarkan Analisis Mikrotremor di Daerah \\ Prambanan Kabupaten Sleman Propinsi DIY dan Klaten Propinsi Jawa Tengah, Indonesia
}

\author{
Hesti $^{1 *}$, Subagyo Pramumijoyo ${ }^{2}$, Djoko Wintolo ${ }^{2}$ \\ ${ }^{1}$ Program Paskasarjana, Teknik Geologi, Universitas Gadjah Mada, Yogyakarta, Indonesia \\ ${ }^{2}$ Teknik Geologi, Universitas Gadjah Mada, Yogyakarta, Indonesia \\ *Email: hestisahaja@gmail.com
}

Submit 20-09-2017; Revised 08-12-2017; Accepted 08-02-2018

\begin{abstract}
Yogyakarta earthquake on Mei 27, 2006 caused Prambanan area get quite severe damage marked by damage of resident house and Prambanan Temple.This study was conducted using data of microtremorsingle station and Yogyakarta earthquake 27 May 2006. Data were analyzed with microtremor HVSR methods to get the value of the dominant frequency $\left(f_{o}\right)$ and amplification $\left(A_{o}\right)$.Furthermore, calculated the value of peak ground acceleration (PGA) in the layers of sedimen bedrock and seismic vulnerability index (Kg) to get ground shear strain $(\gamma)$ value. Prambanan area has a dominant frequency $\left(f_{o}\right)$ value ranges from 0.63-6.78 Hz. Ground shear strain valueranges from 3,5510-5 - 4,0410-2.Each of these factors is then mapped with a division of 4 zones is very high, high, medium, and low.Based on the analysis of all these factors Prambanan area is an area that is vulnerable to the risk of earthquake events.
\end{abstract}

Keywords: Microtremor, HVSR, Dominant Period, Dominant Frequency, PGA, Seismic Vulnerability Index, Ground Shear Strain

\begin{abstract}
Abstrak: Pada gempabumi Yogyakarta 27 Mei 2006 daerah Prambanan mengalami kerusakan yang cukup parah ditandai dengan kerusakan pada rumah penduduk dan bangunan Candi Prambanan. Penelitian ini dilakukan dengan menggunakan data mikrotremor single station dan data gempabumi Yogyakarta 27 Mei 2006. Data mikrotremor dianalisis dengan metode HVSR untuk mendapatkan nilai frekuensi dominan $\left(f_{o}\right)$ dan amplifikasi $\left(A_{o}\right)$. Selanjutnya, dilakukan penghitungan nilai peak ground acceleration (PGA) di lapisan batuan dasar dan indeks kerentanan seismik $(\mathrm{Kg})$ untuk mendapatkan besaran nilai ground shear strain $(\gamma)$ yang kemudian dipetakan. Daerah Prambanan memiliki frekuensi dominan $\left(f_{o}\right)$ berkisar antara 0.63- $6.78 \mathrm{~Hz}$. Nilai ground shear strain berkisar diantara 3,5510-5 - 4,0410-2. Masing-masing faktor tersebut kemudian dipetakan dengan pembagian 4 zona yaitu sangat tinggi, tinggi, menengah, dan rendah. Berdasarkan analisis terhadap semua faktor tersebut maka daerah Prambanan merupakan daerah yang rentan terhadap resiko peristiwa
\end{abstract}

gempabumi.

Katakunci:Mikrotremor, HVSR, Periode Dominan, Frekuensi Dominan, PGA, Indeks Kerentanan Seismik Ground Shear Strain

\section{PENDAHULUAN}

Daerah Yogyakarta dan Klaten merupakan bagian dari jalur gempabumi yang terbentang dari Pulau Sumatera, Jawa, Bali hingga Nusa Tenggara. Sebagai wilayah yang terletak di jalur gempabumi, kondisi fisiografi Daerah Yogyakarta dan Klaten sangat dipengaruni oleh aktivitas tumbukan lempeng Indo-Australia dengan lempeng Eurasia. Kondisi ini menjadikan Daerah Yogyakarta dan Klaten sebagai salah satu kawasan dengan tingkat aktivitas seismik yang tinggi di Indonesia. Selain rawan gempabumi akibat aktivitas tumbukan lempeng, Daerah Yogyakarta juga rawan gempabumi akibat aktivitas beberapa sesar lokal di daratan (Daryono dkk., 2009).

Salah satu daerah yang rawan terhadap gempabumi adalah Kecamatan Prambanan dimana terdapat Candi Prambanan yang merupakan tempat wisatawan banyak berkunjung. Daerah ini terletak di perbatasan antara Yogyakarta dan Klaten. Pada gempabumi Yogyakarta tahun 2006 kawasan Prambanan mendapatkan kerusakan yang cukup parah ditandai dengan rusaknya bangunan Candi Prambanan.

Penelitian di daerah kompleks Candi Prambanan telah dilakukan oleh Djumarma dkk. (2010) dengan menggunakan data mikrotremor. Hasil penelitian ini menunjukkan bahwa di daerah ini tertutup oleh endapan-endapan $\mathrm{Gu}-$ nungapi Merapi muda yang cukup tebal yaitu sekitar 3040 meter dan sebagian besar belum terkonsolidasi kuat sehingga membuat daerah kompleks Candi Prambanan menjadi cukup berisiko ketika diguncang oleh gempabumi. Faktor geologi permukaan memiliki pengaruh yang cukup besar terhadap dampak kerusakan di suatu wilayah akibat terjadinya peristiwa gempabumi.

Penelitian ini dimaksudkan untuk menentukan tingkat 
kerawanan di daerah Prambanan terhadap bahaya gempabumi dengan melakukan analisis terhadap peta persebaran frekuensi dominan $\left(f_{o}\right)$ dan periode dominan $\left(T_{o}\right)$, peta persebaran nilai amplifikasi $\left(A_{o}\right)$, dan peta persebaran ground shear strain $(\gamma)$.

\section{GEOLOGI DAERAH PENELITIAN}

Daerah penelitian terletak di lembah Yogyakarta yang memanjang dari utara ke selatan. Lembah ini merupakan graben yang diisi oleh aliran lahar Merapi. Peta geologi Regional Lembar Yogyakarta (Rahardjo dkk., 1995) dan Peta Geologi Regional Lembar Surakarta dan Giritontro (Surono dkk., 1992) membagi stratigrafi regional daerah penelitian menjadi dua bagian, yaitu stratigrafi yang berumur Tersier dan stratigrafi yang berumur Kuarter. Stratigrafi regional daerah penelitian yang berumur Tersier yaitu Formasi Semilir dan Formasi Kebobutak. Menurut Surono dkk. (1992) Formasi Semilir terdiri dari tuf, breksi batuapung dasitan, batupasir tufan, dan serpih. Menurut Rahardjo dkk. (1995) Formasi Semilir terdiri dari perselingan antara breksi-tuf, breksi batuapung, tuf dasit dan tuf andesit, serta batulempung tufan.. Menurut Surono dkk. (1992) ,bagian atas Formasi Kebobutak terdiri dari perselingan batupasir, batu lempung, dan lapisan tipis tuf asam sedangkan bagian bawah Formasi Kebobutak terdiri dari batupasir, batulanau, batulempung, serpih, tuf dan aglomerat. Menurut Rahardjo dkk. (1995) Formasi Kebobutak terdiri dari breksi andesit, tuf, tuf lapilli, aglomerat, dan sisipan aliran lava andesit.

Menurut Rahardjo dkk. (1995) stratigrafi regional daerah penelitian yang berumur kuarter terdiri dari Endapan Vulkanik Gunungapi Merapi Tua yang terdiri dari breksi, aglomerat, aliran lava, termasuk andesit dan basal mengandung olivin. Endapan Vulkanik Gunungapi Merapi Muda yang terdiri dari tuf, abu, breksi, aglomerat dan aliran lava tak terpisahkan. Endapan Longsoran (Ladu) dari awan panas yang terdiri dari endapan longsoran dan lahar. Daerah penelitian secara regional dikontrol oleh 2 Sesar, yaitu Sesar Opak dan Sesar Dengkeng. Sesar Opak memanjang dari kawasan Parangtritis sampai ke sebelah timur kota Yogyakarta dan Sesar Dengkeng terletak di ujung timur laut Sesar Opak.

\section{MIKROTREMOR}

Lang dan Schwarz (2004) mendefinisikan mikrotremor sebagai derau perioda pendek yang berasal dari sumber buatan. Analisis data mikrotremor dapat dilakukan dengan menggunakan metode Horizontal to Vertical Spectrum Ratio (HVSR). Dalam mitigasi bencana gempabumi, analisis data mikrotremor dapat memberikan informasi nilai fo (frekuensi dominan) pada suatu tempat, yang dapat digunakan untuk perencanaan bangunan tahan gempa. Struktur bangunan yang memiliki nilai f0 yang sama dengan nilai fo daerah sekitarnya akan mengalami resonansi jika terjadi gempabumi, efek dari resonansi tersebut akan memperkuat amplitudo getaran gempabumi atau terjadi amplifikasi pada bangunan sehingga menyebabkan rusaknya bangunan saat terjadi gempabumi.

Amplifikasi merupakan proses alami yang terjadi pada gelombang seismik yang dilepaskan dari gempabumi yang mengalami penguatan (amplifikasi) berdasarkan kondisi batuan yang menyusun suatu daerah (Destegul, 2004). Peristiwa ini dipengaruhi oleh kondisi geologi lokal atau disebut juga site effect.

Nakamura (1996) memperkenalkan parameter indeks kerentanan seismik (Kg) yang dapat menggambarkan tingkat kerentanan lapisan tanah permukaan terhadap deformasi saat terjadi gempabumi. Daerah yang memiliki indeks kerentanan seismik tinggi merupakan daerah dengan kondisi lapisan tanah yang paling kuat dalam merespon getaran gempabumi. Nilai indeks kerentanan sesmik $(\mathrm{Kg})$ dapat dihitung dengan menggunakan persamaan sebagai berikut:

$$
\frac{A_{0}^{2}}{f_{0}}=K_{g}
$$

dimana $A_{o}$ adalah amplifikasi dan $f_{o}$ adalah frekuensi dominan. Fukushima dan Tanaka (1990) merumuskan persamaan empiris untuk menghitung PGA di batuan dasar. Secara sederhana hubungan linier antara logaritmik percepatan getaran tanah maksimum di batuan dasar dengan jarak hiposenter dinyatakan dengan persamaan sebagai berikut :

$$
\begin{gathered}
\log \alpha_{b}=0,41 M_{w}-\log \left(R_{h s}+0,032 \times 10^{0,41 M_{w}}\right) \\
-0,0034 R_{h s}+1,3
\end{gathered}
$$

Dengan $\alpha_{b}$ adalah peak ground acceleration (PGA) di batuan dasar, $M_{w}$ adalah besaran gempabumi dalam skala magnitude momen dan Rhs adalah jarak hiposenter.

Nilai dari parameter indeks kerentanan seismik dan PGA batuan dasar (bedrock) disebut sebagai nilai ground shear strain. Secara matematis nilai ground shear strain dapat dituliskan menurut persamaan Nakamura (1997) sebagai berikut :

$$
\gamma=K_{g} x 10^{-6} x \alpha_{b}
$$

Dimana $K_{g}$ adalah indeks kerentanan seismik dan $\alpha_{b}$ adalah nilai PGA batuan dasar.

\section{DATA DAN METODOLOGI}

Penelitian ini menggunakan beberapa data yaitu data mikrotremor single station, data gempabumi, data sumur dan data kerusakan rumah dan bangunan. Data mikrotremor yang digunakan adalah data yang diukur pada tanggal 28 agustus 5 september 2012 oleh Tim Pyi Soe Thein. Data gempabumi yang digunakan adalah gempabumi Yogyakarta pada 27 Mei 2006 dengan magnitude momen 6.3. Sedangkan data sumur bor yang digunakan dengan kedalaman 30 meter.

Metode dalam penelitian ini memuat beberapa analisis yang dilakukan, yaitu analisis horizontal to vertical spectral ratio (HVSR), analisis peak ground acceleration (PGA), analisis ground shear strain $(\gamma)$. Pengolahan data 
mikrotemor menggunakan metode HVSR dengan menggunakan software Geopsy versi 2.9.0. Software Geopsy merupakan produk dari proyek SESAME yang merupakan proyek multinasional (European Project - Site Effects Assessment using Ambient Exitation, 2001).

Kurva HVSR terdiri dari komponen vertical dan horizontal. Komponen vertikal menunjukkan nilai amplifikasi $\left(A_{o}\right)$ dan komponen horizontal menunjukkan nilai frekuensi dominan $\left(f_{o}\right)$. Dari nilai frekuensi dominan $\left(f_{o}\right)$ maka dapat diperoleh nilai periode dominan $\left(T_{o}\right)$ dengan hubungan yang saling berkebalikan.

Nilai amplifikasi $\left(A_{o}\right)$ dan frekuensi dominan $\left(f_{o}\right)$ dapat digunakan untuk mendapatkan nilai indeks kerentanan seismik $\left(K_{g}\right)$ dengan menggunakan persamaan (1). Nilai indeks kerentanan seismik digunakan sebagai salah satu parameter untuk menghitung besaran nilai ground shear strain di Prambanan. PGA batuan dasar (bed rock) dihitung berdasarkan persaman (2) dimana besaran nilai PGA batuan dasar diperlukan untuk menentukan besaran nilai ground shear strain.

Analisis Ground shear strain $(\gamma)$ dilakukan untuk mengetahui kemampuan meregang atau bergeser yang dialami oleh suatu material lapisan tanah ketika terjadi gempabumi didaerah penelitian. Besarnya nilai Ground shear strain dihitung dengan menggunakan persamaan (3) dimana nilainya berbanding lurus dengan besarnya indeks kerentanan seismik dan PGA dibatuan dasar. Nilai ground shear strain digunakan untuk membuat peta persebaran ground shear strain di daerah Prambanan. Kemudian dilakukan analisis terhadap resiko peristiwa gempabumi.

\section{HASIL DAN DISKUSI}

\subsection{Frekuensi Dominan $\left(f_{o}\right)$ dan Periode Dominan $\left(T_{o}\right)$}

Nilai frekuensi dominan yang diperoleh dari analisis HVSR berkisar antara 0.63- 6.78 Hz. Peta persebaran frekuensi dominan (fo) daerah Prambanan dibagi dalam 4 zona, yaitu zona berwarna merah, kuning, biru dan hijau. Frekuensi terendah ditunjukkan dengan warna hijau dimana nilai frekuensi dominan kurang dari $0,8 \mathrm{~Hz}$. Frekuensi menengah ditunjukkan dengan warna biru dengan nilai antara 0,8 $0,9 \mathrm{~Hz}$. Frekuensi tinggi ditunjukan dengan warna kuning dengan nilai antara 0,9 1,0 Hz. Frekuensi sangat tinggi ditunjukkan dengan warna merah dan dengan nilai frekuensi dominan lebih dari $1 \mathrm{~Hz}$. Daerah yang memiliki frekuensi dominan rendah yaitu ada di desa Bokoharjo, Tlogo dan Kebondalem Kidul. Daerah yang memiliki frekuensi dominan menengah yaitu sebagian besar terletak di desa Bokoharjo, desa Kebondalem Kidul, desa Taji, dan desa Tlogo. Frekuensi dominan tinggi sebagian besar terletak di desa Bugisan, Kokosan, kebondalem Lor, Bokoharjo, Kebondalem Kidul, dan Taji. Frekuensi dominan sangat tinggi sebagian besar terletak di desa Tlogo, Bugisan dan Kokosan. Secara lebih detail dapat dilihat pada Gambar 1.

Hasil pengolahan data mikrotremor dengan metode HVSR secara umum memperlihatkan bahwa di daerah Prambanan memiliki nilai frekuensi dominan yang tidak begitu tinggi yaitu $<2 \mathrm{~Hz}$. Frekuensi dominan yang rendah menunjukkan bahwa daerah Prambanan memiliki ketebalan sedimen yang tebal. Ini berdasarkan hubungan $f_{o}=$
$\frac{V}{4 H}$, maka frekuensi dominan $\left(f_{o}\right)$ dapat digunakan untuk mengestimasi ketebalan sedimen $(\mathrm{H})$ dan kecepatan shear wave (V) (Bard, 2000 dalam Daryono, 2009). Hal ini juga didukung dengan data bor di Candi Sewu dan Candi Plaosan yang terletak di desa Bugisan, Kecamatan Prambanan, kabupaten Klaten dimana pada kedalaman sumur 50 meter masih merupakan lapisan sedimen yang berupa batu pasir. Kondisi fisografi daerah penelitian yang berada pada bagian Kaki Merapi juga turut memberikan sumbangsih tebalnya sedimen didaerah penelitian yang letaknya dibagian bawah sehingga mendapat lebih banyak endapan vulkanik dari Gunungapi Merapi Muda.

Dengan demikian dari nilai $f_{o}$ hasil pengukuran mikrotremor dapat digunakan untuk mengestimasi pola persebaran ketebalan sedimen di daerah penelitian. Dari persebaran nilai $f_{o}$ yang bervariasi menunjukkan ketebalan sedimen yang bervariasi. Bagian tengah daerah penelitian memiliki nilai frekuensi dominan $\left(f_{o}\right)$ lebih rendah dibandingkan dengan bagian utara dan selatan daerah penelitian sehiingga diperkirakan daerah penelitian bagian tengah memiliki ketebalan sedimen yang lebih tebal dari bagian utara dan selatan daerah penelitian. Nilai frekuensi dominan berbanding terbalik dengan nilai periode dominan. Semakin kecil nilai frekuensi dominan maka nilai periode dominan semakin besar. Dari nilai frekuensi dominan yang diperoleh dari analisis HVSR selanjutnya dapat dicari nilai periode dominan $\left(T_{o}\right)$.

Nilai perioda dominan hasil penelitian ini berada pada rentang 0.15 detik sampai dengan 1.59 detik. Perioda dominan tanah $\left(T_{o}\right)$ dari hasil analisis Horizontal Vertical to Spectra Ratio (HVSR) dapat merepresentasikan ketebalan lapisan sedimen dan jenis lapisan sedimen tersebut (Zhao dkk., 2004). Perioda dominan tinggi diduga tersusun oleh lapisan sedimen yang lunak dan tebal, sedangkan perioda dominan rendah mengindikasikan lapisan sedimen keras dan tipis. Menurut Zhao dkk. (2004) jika nilai periode dominan sedimen 0,6 detik maka tergolong ke dalam golongan sedimen lunak. Sebagian besar daerah penelitian memiliki nilai periode dominan lebih dari 0,6 detik, sehingga daerah penelitian merupakan lapisan sedimen lunak.

Lapisan sedimen lunak pada daerah penelitian ini berdasarkan peta geologi merupakan endapan kuarter vulkanik gunungapi Merapi Muda. Hasil penelitian ini juga sesuai dengan data sumur yang telah diperoleh di Candi Sewu dan Candi Plaosan, dimana litologi penyusun lapisan sedimen merupakan lapisan sedimen lunak berupa batu pasir dengan ketebalan sedimen $50 \mathrm{~m}$.

\subsection{Amplifikasi $(A o)$}

Besarnya nilai amplifikasi diperoleh dari analisis terhadap kurva HVSR. Dimana nilai puncak merupakan nilai amplifikasi. Nilai amplifikasi di daerah penelitian berkisar antara 0.75-12.81 kali. Peta sebaran nilai amplifikasi daerah penelitian dibagi menjadi 4 zona, yaitu zona berwarna merah, kuning, biru dan hijau. Amplifikasi terendah ditunjukkan dengan warna hijau dimana nilai amplifikasi kurang dari 2 kali. Amplifikasi menengah ditunjukkan dengan warna biru dengan nilai antara 2-3 kali. Amplifikasi tinggi ditunjukan dengan warna kuning dengan nilai antara 3-4 kali. Amplifikasi sangat tinggi ditunjukkan dengan warna merah dengan nilai lebih dari 4 kali. 


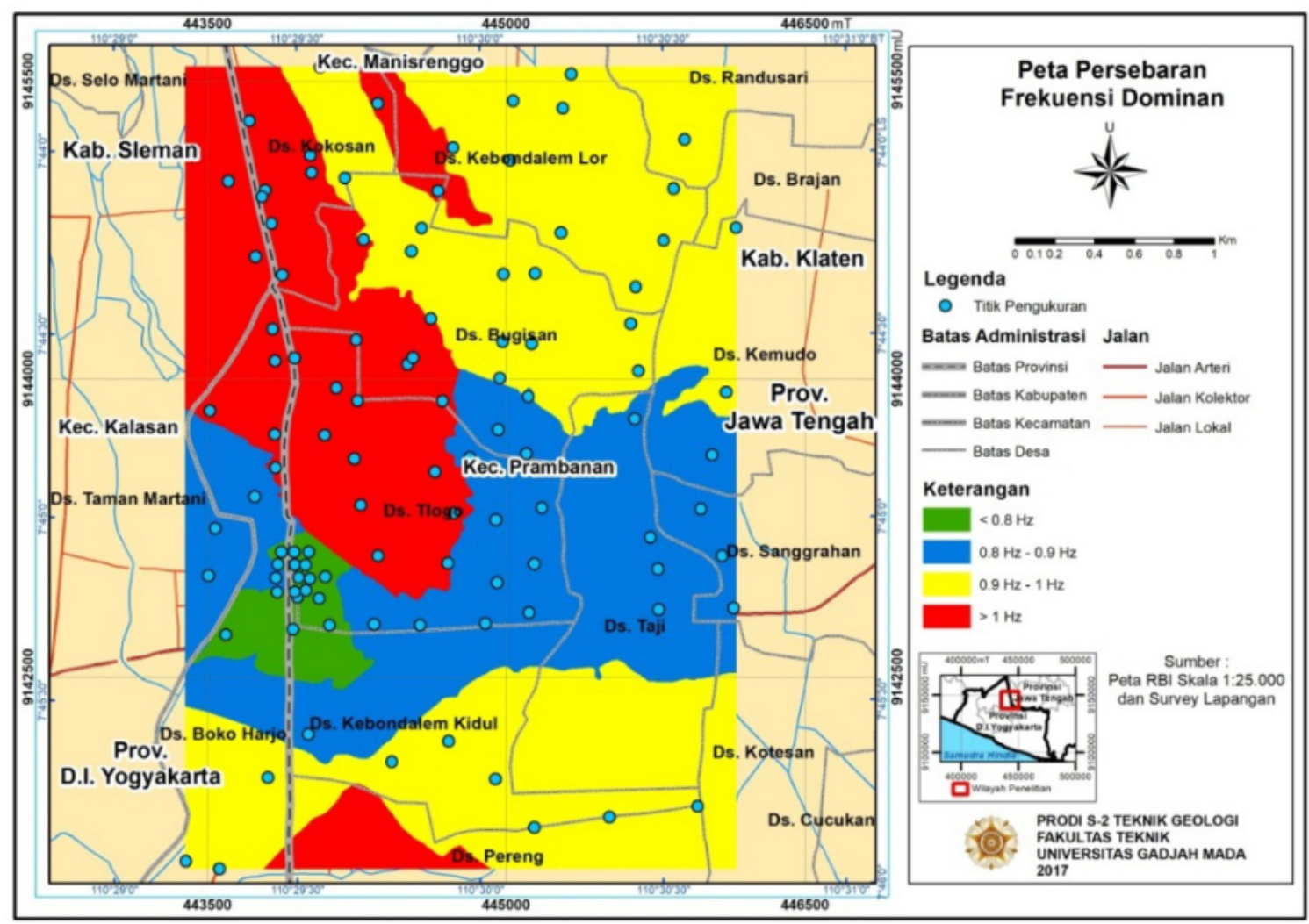

Gambar 1. Peta persebaran nilai frekuensi dominan di daerah Prambanan.

Daerah yang memiliki amplifikasi sangat tinggi sebagian besar terletak di desa Taji, Bokoharjo, dan Taman Martani. Daerah yang memiliki amplifikasi tinggi sebagian besar terletak di desa Bokoharjo, Kebondalem Kidul dan Tlogo. Daerah yang memiliki amplifikasi menengah berada di desa Tlogo, bugisan, kokosan dan kebondalem Lor. Daerah yang memiliki amplifikasi rendah berada di desa bugisan dan Kokosan. Secara detail dapat dilihat pada Gambar 2.

Besaran amplifikasi memiliki pengaruh yang cukup signifikan terhadap resiko kerusakan di suatu wilayah terhadap peristiwa gempabumi. Nilai amplifikasi lapisan sedimen merepresentasikan adanya perubahan percepatan gerakan tanah dari batuan dasar ke permukaan atau perubahan kecepatan gerakan gelombang geser dari batuan dasar ke sedimen (Partono dkk., 2013).

Secara geologi daerah penelitian dilapisi oleh lapisan sedimen endapan gunungapi Merapi Muda yang berumur kuarter berupa batu pasir dengan ketebalan lapisan sedimen kurang lebih 50 meter berdasarkan data sumur di Candi Sewu dan Candi Plaosan. Suatu daerah dengan kondisi geologi sedimen lunak dan tebal lebih mudah mengalami amplifikasi ketika terjadi peristiwa gempabumi.

Variasi nilai amplifikasi pada lapisan sedimen menggambarkan semakin tinggi nilai amplifikasi sedimen maka lapisan tersebut merupakan lapisan lunak tebal atau bisa diakibatkan oleh adanya perbedaan parameter perambatan gelombang di batuan dasar dan sedimen yang semakin besar sehingga akan menimbulkan penguatan getaran gelombang gempa atau amplifikasi ketika terjadi gempa bumi. Sehingga suatu daerah dengan nilai ampli-
Tabel 1. ata Kerusakan Rumah di Prambanan pada Gempabumi Yogyakarta 27 Mei 2006 (BPBD Klaten)

\begin{tabular}{|c|l|r|r|r|}
\hline No & Nama Desa & $\begin{array}{r}\text { Rusak } \\
\text { Total }\end{array}$ & $\begin{array}{r}\text { Rusak } \\
\text { Berat }\end{array}$ & $\begin{array}{r}\text { Rusak } \\
\text { Ringan }\end{array}$ \\
\hline 1 & Kokosan & 9 & 122 & 380 \\
\hline 2 & $\begin{array}{l}\text { Kebondalem } \\
\text { Kidul }\end{array}$ & 412 & 419 & 111 \\
\hline 3 & $\begin{array}{l}\text { Kebondalem } \\
\text { Lor }\end{array}$ & 42 & 90 & 193 \\
\hline 4 & Taji & 691 & 314 & 87 \\
\hline 5 & Bugisan & 196 & 416 & 207 \\
\hline
\end{tabular}

fikasi tinggi mendapatkan guncangan yang kuat ketika terjadi peristiwa gempabumi.

Dapat kita lihat pada Gambar 3 dimana desa Taji berada pada zona amplifikasi sangat tinggi sehingga kemungkinan daerah ini mendapat guncangan yang lebih kuat dari daerah yang lainnya. Hal ini sejalan dengan data kerusakan di Prambanan ketika terjadi peristiwa gempabumi 27 Mei 2006 dimana desa Taji mendapatkan kerusakan yang paling parah dibanding daerah yang lainnya. Kemudian desa kebondalem Kidul juga mendapatkan kerusakan yang parah dimana desa ini berada pada zona amplifikasi tinggi, seperti yang ditunjuukan pada Tabel 1.

\subsection{Ground Shear Strain $(\gamma)$}

Perhitungan nilai ground shear strain menggunakan persamaan (3). Nilai ground shear strain pada daerah penelitian berkisar diantara 3.55 10-5 - 4.04 10-2. Peta sebaran 


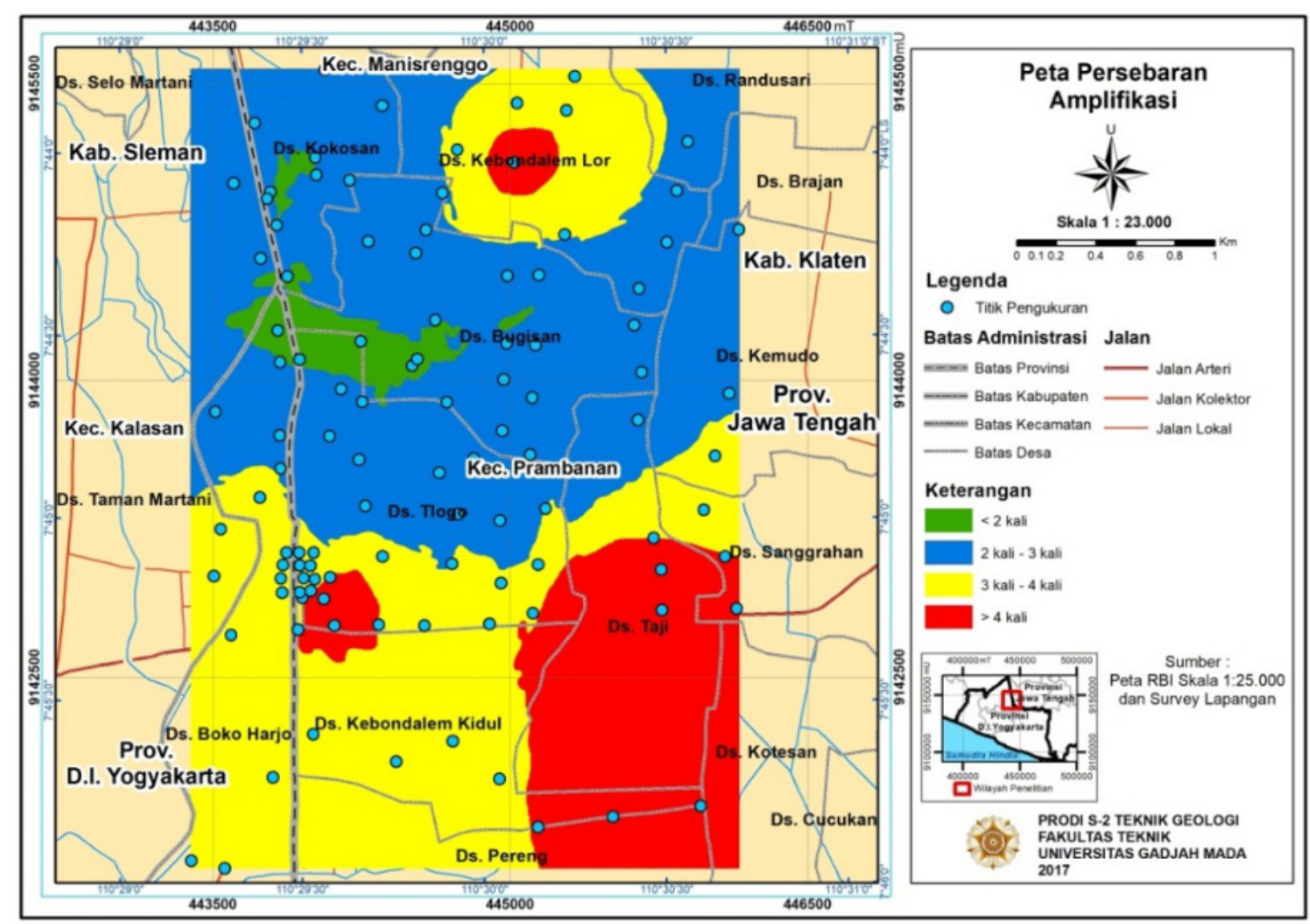

Gambar 2. Peta persebaran nilai amplifikasi daerah Prambanan.

nilai ground shear strain di daerah Prambanan dibagi menjadi 4 zona, yaitu zona berwarna merah, kuning, biru dan hijau. Ground shear strain terendah ditunjukkan dengan warna hijau dengan nilai kurang dari 0,001. Ground shear strain menengah ditunjukkan dengan warna biru dengan nilai berkisar antara 0,001-0,002. Ground shear strain tinggi ditunjukkan dengan warna kuning dengan nilai berkisar antara 0,002-0,003. Ground shear strain sangat tinggi ditunjukkan dengan warna merah dengan nilai lebih dari 0,003.

Daerah yang memiliki ground shear strain yang sangat tinggi mencakup sebagian besar wilayah penelitian yaitu di desa Bokoharjo, Kebondalem Kidul, Tlogo, Taji, Taman Martani dan Kebondalem Lor. Daerah yang memiliki ground shear strain yang tinggi meliputi desa Tlogo, Kokosan, Bugisan dan Kebondalem Lor. Daerah yang memiliki ground shear strain menengah yaitu di desa Bugisan, Tlogo, Kebondalem Lor dan Kokosan. Daerah yang memiliki ground shear strain rendah yaitu di desa Bugisan dan kokosan. Secara lebih detail dapat dilihat pada Gambar 3.

Menurut Ishihara dan Ansal (1982) lapisan sedimen memiliki sifat plastis pada $\gamma=1 \times 10-3$, sedangkan pada $\gamma>1 \times 10-3$ lapisan sedimen dapat mengalami deformasi dan likuifaksi. Dapat kita lihat pada Gambar 3 hampir seluruh wilayah penelitian memiliki nilai ground shear strain $(\gamma)$ lebih dari 1 x 10-3, dan hanya sebagian kecil wilayah yang memiliki ground shear strain $(\gamma)$ kurang dari $1 \times 10^{-3}$, ini berarti bahwa daerah penelitian merupakan daerah yang potensial mengalami deformasi dan likuifaksi ketika terjadi gempabumi.

Secara geologi daerah penelitian tertutupi oleh sedimen lunak dan tebal berupa batupasir dengan ketebalan $50 \mathrm{~m}$. Jenis batuan pasir yang memiliki struktur halus dan dapat meloloskan air dan bersifat lepas-lepas lagi tebal cenderung tidak memiliki kohesi (ikatan antar butir) yang kuat, maka tingkat kemudahan tergoncang oleh getaran lebih besar dan bersifat meneruskan getaran, sehingga pada saat terjadi gempabumi bangunan atau infrastruktur di atasnya akan lebih mudah hancur. Daerah penelitian tertutupi oleh lapisan sedimen gunungapi Merapi Muda yang berumur Kuarter. Batuan dengan umur Kuarter akan memiliki pengaruh yang lebih besar dibandingkan dengan umur selain itu karena sifat batuannya cenderung lebih lepas-lepas atau tidak padu karena umurnya yang lebih muda.

\section{KESIMPULAN}

Daerah penelitian merupakan daerah yang rentan terhadap resiko peristiwa gempabumi dengan analisis sebagai berikut: (1) Daerah penelitian memiliki lapisan sedimen yang tebal dan lunak ditandai dengan nilai frekuensi dominan $\left(f_{o}\right)$ yang rendah dan periode dominan $\left(T_{o}\right)$ yang tinggi. (2) Sebagian besar daerah penelitian memiliki amplifikasi lebih dari 2 kali sehingga dapat merasakan guncangan yang lebih kuat ketika terjadi gempabumi. (3) Hampir seluruh wilayah penelitian memiliki nilai ground shear strain $(\gamma)$ yang tinggi yaitu lebih dari 1 10-3 sehingga rentan terhadap peristiwa gempabumi karena potensial mengalami deformasi dan likuifaksi. 


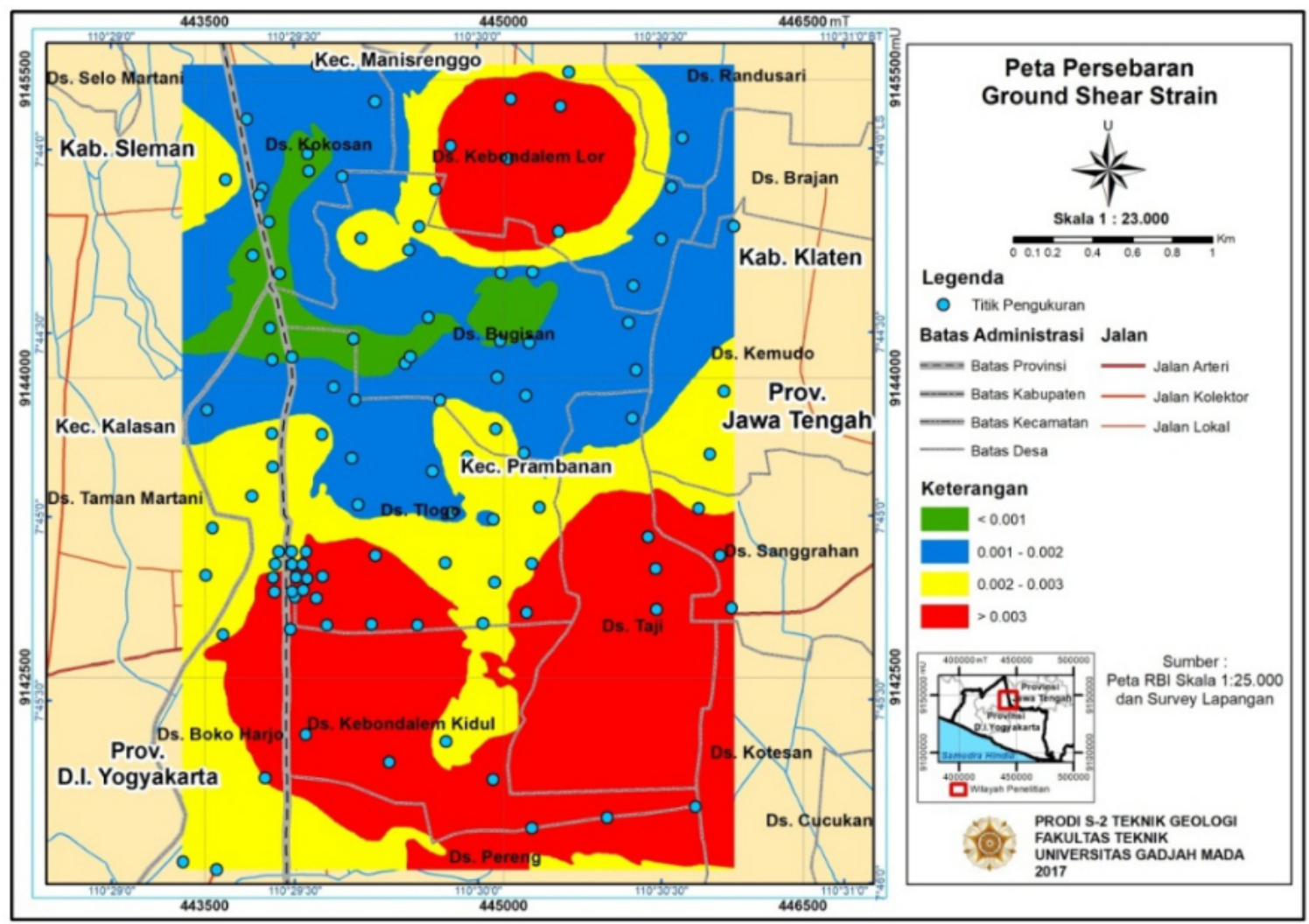

Gambar 3. Peta persebaran nilai ground shear strain daerah Prambanan.

\section{UCAPAN TERIMA KASIH}

Penulis ingin mengucapkan terimakasih kepada Mr Pyi Soe Thein beserta timnya yang telah melakukan pengumpulan data di lapangan. Ucapan terimakasih juga penulis sampaikan kepada civitas akademik UGM yang turut mendukung penulisan makalah ini.

\section{DAFTAR PUSTAKA}

Daryono, Sutikno, Sartohadi, J., Dulbahri, dan Brotopuspito, K.S., 2009, Efek Tapak Lokal (Local Site Effect) di Graben Bantul Berdasarkan Pengukuran Mikrotremor, International Conference Earth Science and Technology, Jurusan Teknik Geologi, Fakultas Teknik, U.G.M. h:119-124.

Djumarma, A., Soehaimi, A., dan Mariyono, 2010, Geoseismic Research Concerning The Safeguard from The Earthquake Hazards to the world heritage of Prambanan Temple, Bulletin Vulkanologi dan Bencana Geologi, Vol. 5 No.2, Agustus 2010 : 7-13.

Destegul, U., 2004, Sensitivity Analysis of Soil Site Response Modelling in Seismic Microzonation for Lalitpur Nepal, Enschede : Netherlands.

Fukushima, Y., dan Tanaka, T., 1990, A new attenuation relation for peak horizontal acceleration of strong earthquake ground motion in Japan.Bulletin of the Seismological Society of America, 80(4),August $1990: 757783$.

Ishihara, K., dan Ansal, A. M., 1982, Dynamic Behavior of Soils, Soil Amplification and Soil Structure Interaction, UNESCO.

Lang, D.H., dan Schwarz, J., 2004, Instrumental Subsoil Clasification of Californian Strong Ground Motion SiteBased on Single Measurments, Volume 1,pp.6.

Nakamura, Y., 1996, Real Time Information Systems for Seismic
Hazards Mitigation UrEDAS, HERAS and PIC, Quarterly Report of RTRI, Vol.37, No. 3, 112-127.P.

Nakamura, Y., 1997, Seismic Vulnerability Indices For Ground and Structures Using Microtremor, World Congress on Railway Research in Florence, Italy.

Partono, W., Irsyam, M., Prabandiyani, dan S., Marif, S., 2013, Aplikasi Metode HVSR pada Perhitungan Faktor Amplifikasi Tanah di Kota Semarang, Jurnal Media Komunikasi Teknik Sipil, Vol.19 No 2, Desember 2013: 125-134.

Rahardjo, W., Sukandarrumidi, dan Rosidi, H. M. D., 1995, Peta Geologi Lembar Yogyakarta, Pusat Penelitian dan Pengembangan Geologi, Bandung.

Surono, Toha, B., Sudarno, I., 1992, Peta Geologi Lembar Surakarta-Giritontro, Pusat Penelitian dan Pengembangan Geologi, Bandung.

Zhao, J.X., Irikura, K., Zhang, J., Fukhusima, Y., Somerville,P.G., Asano, A., Saiki, T., Okada, H., dan Takahashi, T., 2004, Site Classification for Strong-Motion Stations in Japan Using $\mathrm{H} / \mathrm{V}$ Response Spectral Ratio. Paper No. 1278, 13th World Conference on Earthquake Engineering, Canada. 